\title{
Human Biology of Weight Maintenance after Weight Loss
}

\author{
Edwin C.M. Mariman \\ Department of Human Biology, NUTRIM School for Nutrition, Toxicology and Metabolism, \\ Maastricht University Medical Centre, Maastricht, The Netherlands
}

\author{
Key Words \\ Obesity $\cdot$ Weight regain $\cdot$ Weight maintenance $\cdot$ Physiology
}

\begin{abstract}
One year after losing weight, most people have regained a significant part of the lost weight. As such, weight regain after weight loss has a negative impact on human health. The risk for weight regain is determined by psychosocial and behavioral factors as well as by various physiological and molecular parameters. Here, the latter intrinsic factors are reviewed and assembled into four functional modules, two related to the energy balance and two related to resistance against weight loss. Reported genetic factors do not reveal additional functional processes. The modules form nodes in a network describing the complex interactions of intrinsically determined weight maintenance. This network indicates that after an initial weight loss persons with a high baseline fat mass will most easily succeed in maintaining weight, because they can lose fat without raising stress in adipocytes and at the same time spare fat-free mass. However, continued weight loss and weight maintenance requires extra measures like increased physical activity, limited energy intake and a fat-free sparing composition of the diet. Eventually, this network may help to design novel therapeutic measures based on preventing the return effect of specific plasma factors or by preventing the accumulation of adipocyte cellular stress.




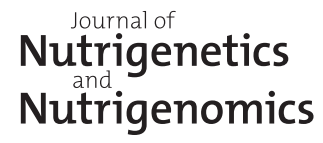

\begin{tabular}{l|l|}
\hline J Nutrigenet Nutrigenomics 2012;5:13-25 \\
\hline $\begin{array}{l}\text { DOI: 10.1159/000337081 } \\
\text { Published online: March 30, } 2012\end{array}$ & $\begin{array}{l}\text { @ } 2012 \text { S. Karger AG, Basel } \\
\text { www.karger.com/jnn }\end{array}$ \\
\hline
\end{tabular}

Mariman et al.: Human Biology of Weight Maintenance after Weight Loss

\section{Introduction}

Obesity has become a worldwide threat to public health and public health systems, but fortunately there is an easy remedy, i.e., losing weight either by dietary intervention, increased physical activity, or pharmacological and/or surgical treatment. This is usually successful, but then a hard time follows trying to keep the weight at its reduced level, which seems impossible for most people. While meta-analysis suggests that after a small weight loss long-term maintenance is achievable [1], studies indicate that between $35 \%$ and $80 \%$ of subjects who lost at least $10 \%$ of their body weight do not succeed in maintaining this weight for over 1 year [2-6]. Since reducing weight is of importance from a health perspective, it is necessary to clarify the factors and mechanisms determining the chance for successful weight maintenance. Psychosocial and lifestyle influences are obviously involved [7], but recent studies lead to a growing awareness of the effect of various physiological and molecular parameters. Recently, Maclean et al. [7] have excellently reviewed this subject combining rodent data with human studies. However, one can argue that rodents and humans may differ considerably in physiology, genetic variability, impact of psychosocial factors, chronobiology, etc. [8]. Taking this into account and because primary weight gain and weight regain are (partly) different biological processes, for the present review only data are considered from human studies directly addressing weight regain after weight loss. This leads to four functional modules that contribute to the risk for weight regain.

\section{Module 1: Energy Expenditure by Fat-Free Mass}

Several studies have pointed out that weight or weight-related parameters are associated with the risk for weight regain. In women who lost $10 \%$ of body weight, weight regain after 1 year was significantly associated with maximum lifetime weight or BMI [9]. A high baseline BMI, waist circumference or fat mass indicated a lower weight regain 1 year after weight loss by a very low-calorie diet (VLCD) as reported by Vogels and Westerterp-Plantenga [10]. Even after 2 years, a high baseline BMI and fat mass were still associated with $<10 \%$ weight regain $[11,12]$, which was confirmed in another study [13]. Also, the percentage of body fat lost during the VLCD was found to be negatively associated with the percentage of body weight regain [11]. Percentage weight regain was negatively correlated to baseline resting metabolic rate [12], indicating that a high resting metabolic rate promotes successful weight maintenance after weight loss. As the closely related basal metabolic rate is largely determined by fat-free mass $[14,15]$, it can be assumed that a fat-free mass sparing effect is strongly involved in the risk for weight regain [10]. In this respect, the ratio of fat mass/fat-free mass in the lost weight could be easily higher for people with a high baseline body fat content, giving them an advantage with respect to the risk for weight regain.

The importance of preserving fat-free mass is also related to the fact that this body component is highly involved in energy expenditure by physical activity. In fact, the level of physical activity is a commonly recognized factor influencing weight regain. Increased body weight is associated with reduced physical activity, and so is rebound weight gain, but at the same time energy expenditure does not decrease much, because with increasing body weight the amount of labor needed to perform similar activities as before increases in parallel [16, 17]. Reversely, when weight is lost, activity-related energy expenditure (AEE) is considerably reduced $[18,19]$. In fact, the daily energy requirement and total energy expenditure drop an extra $\sim 15 \%$ below the level that would be expected based on the new body weight [20-22], and this drop in energy expenditure is accompanied by changes in the activities of energy-regulating enzymes in the skeletal muscle [23]. It persists for more than a year if the reduced body weight is maintained [24] and leads to a positive energy balance after weight loss that can be (partly) compensated 
for by an extra increase in the level of physical activity. Failure to maintain such a level will add to the risk of weight regain. A long-term study among 4,558 premenopausal women who intentionally had lost $>5 \%$ of their body weight showed that $80 \%$ of them had regained $>30 \%$ of the lost weight after 6 years, but that weight regain was less in women who maintained a moderate daily activity [25]. Further, a decrease in energy expenditure ideally should be accompanied by a sufficient reduction in energy intake, helping to keep the risk for weight regain low [26].

An interesting observation was reported by Tremblay and Chaput [27] in a study on weight loss by reduced energy intake of obese men to a level of resistance to further weight loss. In this study, fat-free mass did not change, but fat mass did. At the end of the study, loss of fat mass was positively associated with reduction in thermogenesis, a form of energy expenditure to which both non-fat tissues and adipose tissue contribute. It suggests that reduction of thermogenesis can cause resistance to lose fat. In this regard, lipophilic pollutants stored in the fat and released upon fat loss [28] are suspected to induce reduction of thermogenesis, thereby stopping fat loss and further release of those potentially harmful pollutants [29]. It has been proposed that loss of (activity of) brown adipose tissue is involved in this reduction of thermogenesis, but this has to be further investigated [30].

The role of the body fat-free mass in weight maintenance has led to a search for ways to preserve this component during weight loss. In this respect, several studies into the macronutrient composition of the diet have been performed. With regard to carbohydrates, the glycemic load (GL) of the food seems important, which is the glycemic index (GI) multiplied by the amount of carbohydrates in a food. It was reported that compared to a low-fat diet a low-GL diet has a smaller lowering effect on resting energy expenditure, leads in addition to a reduced feeling of hunger, can minimize postprandial insulin secretion and helps to maintain insulin sensitivity [31]. This may explain at least in part why a low-GI diet leads to greater weight loss [32]. Equally interesting is the influence of the protein percentage of the diet on weight management. High protein diets, besides inducing higher energy expenditure by increasing thermogenesis and besides stimulating satiety, have a sparing effect on fat-free mass that in some individuals may lead to an improved metabolic profile [32-34]. Experiments indicate that different amino acids have a specific activity with respect to the observed effects [34] with a special role for branched-chain amino acids, in particular leucine [35, 36].

The above findings indicate that low-GL and high-protein diets or a combination would be advantageous for weight maintenance after weight loss. This aspect of dietary macronutrient composition was recently investigated in the Diogenes study [37] in which overweight/ obese subjects lost $>8 \%$ of body weight during an 8-week low-calorie diet (3.4-4.2 MJ/day). Testing the effect of GI and protein content during a 6-month follow-up period, it was observed that a modest reduction of GI and a modest increase in protein content indeed improved maintenance of lost weight. In accordance, significant weight regain was seen in the group taking a high-GI/low-protein diet [38]. To have an optimal chance for weight maintenance after weight loss by caloric restriction, based on the role of fat-free mass and energy expenditure it is advised to increase the protein content of the diet and preferably decrease its GI while increasing physical activity throughout the weight loss phase and the subsequent weight maintenance period.

\section{Module 2: Energy Regulation by Metabolic Hormones}

For weight maintenance after weight loss, careful control of energy intake is necessary. Major mediators for this are the metabolic hormones regulating the feelings of hunger and satiety, and one would expect that their behavior has been profoundly studied in the context of weight maintenance. However, research has largely been centered around leptin. 
During weight loss, fat mass reduces and as expected, plasma leptin levels drop. In fact, leptin levels decrease proportionally much more than fat mass. As a typical example, in a recent study in which overweight subjects lost about $20 \%$ of their fat mass, leptin levels on average dropped by $50 \%[39,40]$. Such a reduction in leptin level was found with different protocols of weight loss pointing to a uniform effect [40,41]. Rosenbaum et al. [42] suggested that this drop of leptin leads to leptin deficiency in the brain, creating a high risk for increased energy intake during the after-weight-loss period. Interestingly, experiments in the mouse indicated that part of the physiological consequences of starvation can be prevented by leptin injection compensating the leptin drop [43]. Because subjects who lose $10 \%$ of their body weight show symptoms characteristic of humans with leptin deficiency, similar experiments were performed with human volunteers. When leptin was injected during the maintenance period, a reversal was noticed of activities in those regions of the brain that are typical for energy intake regulation [44].

In addition to characteristics of energy intake, leptin injections reverse several other weight loss-induced changes to the pre-weight loss state including energy expenditure, skeletal muscle work efficiency, and sympathetic nervous system tone [42]. Goldsmith et al. [45] recently demonstrated that mechanical efficiency of skeletal muscle at low work load correlates with the change by weight loss in the ratio of glycolytic to oxidative enzyme activity, which links weight loss-induced changes in AEE to changes at the muscle biochemical level. Eventually, studies like this may help to explain why AEE drops significantly below the level that would be expected based on changes in body weight and composition [20-22]. The idea is now that leptin or similar drug treatment may delimit the negative physiologic consequences of weight loss with a positive effect on weight maintenance.

In search for more mechanistic insight, Rosenbaum et al. [46] observed that $10 \%$ weight loss is not only accompanied by a reduction of circulating concentrations of leptin, but also of triiodothyronine (T3) and thyroxine (T4), which persists during maintenance of the newly acquired weight. When they subsequently adjusted leptin to the pre-intervention level, also the thyroid hormone levels were reversed, suggesting a coordinated action between leptin and thyroid hormones. This observation is in line with leptin supplementation in women with hypothalamic amenorrhea, which led to increased thyroid hormone levels [47]. It shows that the hypothalamic-pituitary-thyroid axis is important for weight maintenance [42, 44], which is under the influence of leptin and possibly other metabolic hormones.

The link between weight maintenance and leptin was substantiated by Crujeiras et al. [48] who reported in women a correlation of weight regain with leptin levels at the beginning and at the end of the weight loss period, as well as with the change of leptin over that period. The fact that higher baseline plasma levels seemed to predict weight regain had been reported before [13]. Further, in a study with a weight loss phase of 6 months and a follow-up of 7-24 months, Erez et al. [49] showed that weight regain was predicted by a relatively strong decrease in weight together with a decrease in leptin. On the other hand, conflicting findings have been reported as well. Vogels et al. [50] measured the leptin drop in successful and nonsuccessful weight maintainers after weight loss by a 6-week VLCD. The unsuccessful group ( $\mathrm{n}=99)$ lost $7.2 \mathrm{~kg}$ body weight (4.6 kg fat mass) and regained $4.9 \mathrm{~kg}$ within 1 year, whereas the successful group $(\mathrm{n}=21)$ lost a comparable $7.6 \mathrm{~kg}$ body weight $(4.9 \mathrm{~kg}$ fat mass) and lost an additional $1.8 \mathrm{~kg}$. During the VLCD, leptin dropped by $17.9 \mathrm{ng} / \mathrm{ml}$ in the unsuccessful group and by $18.0 \mathrm{ng} / \mathrm{ml}$ in the successful group, suggesting that the change of leptin is not predicting success of weight maintenance after weight loss. This finding is in keeping with the outcome of an earlier study by Wing et al. [51] who found no predictive power of baseline leptin concentrations, nor of the changes in leptin levels during weight loss, on weight maintenance. The different outcome of all these studies may be due to ethnic background, limited statistical power, and difference in study design. 
For ghrelin, similar findings have been reported as for leptin. Higher baseline ghrelin levels seem to predict better weight maintenance after weight loss [48]. In a 12-month weight loss intervention, it was found that baseline ghrelin levels are related to the degree of weight loss. In the same study it was observed that after 6 months plasma ghrelin concentration was increased but returned to its original level at 12 months, suggesting that ghrelin cannot have a long-term effect on body weight [52]. In a study in women on the effect of milk on appetite sensation during weight loss by a calorie-restricted diet, it was shown that the change in plasma ghrelin concentration is related to the change in desire to eat [53]. Apparently, manipulating the ghrelin concentration by diet composition could have potential for weight regulation.

Recently, the plasma concentration of an elaborate set of metabolic hormones was studied during weight loss and a 1-year follow-up period including insulin, leptin, ghrelin, pYY, gastric inhibitory peptide, GLP1, amylin, pancreatic polypeptide, and CCK. Although after 1 year on average $40 \%$ of the weight had been regained, the plasma level of some hormones like pYY and CCK still reflected the after-weight loss situation [40]. Since this promotes appetite, trying to adjust the levels of those hormones might be a way to lower the risk for weight regain. Altogether, studies like this show that it is important to obtain knowledge about the behavior of metabolic hormones during weight loss and maintenance. Such knowledge may easily lead to preventive or therapeutic measures from the perspective of energy intake regulation.

\section{Module 3: Physiologic Resistance against Weight Loss}

Physiologic activities of tissues and organs in our body are reflected in plasma metabolite concentrations. Remarkably, for some plasma components the change in concentration during weight loss reverts during the weight maintenance phase and the concentration may even return to the pre-weight loss level. This includes triglycerides, free fatty acids, $\beta$-hydroxybutyrate, glucose, HDL, and total cholesterol. Sjöström et al. [54] as well as others observed that the original level can be reached again 2 years after the weight loss period [54, 55]. Those observations comply with a model in which the plasma levels are fixed in a homeostatic framework. During weight loss under a negative energy balance plasma concentrations deviate from the framework levels, but as soon as energy balance is re-established, levels are brought back to fit into the homeostatic framework. In this regard, the plasma metabolites may reflect processes in the body that resist weight change. Ultimately, they may act as a factor driving the weight back to its original value. As mentioned above, a similar observation was made for the metabolic hormone ghrelin in a 12-month weight loss intervention during which its plasma concentration first increased but then returned to its original level [52]. Diepvens et al. [56] observed that the return effect may even occur already during the late weight loss phase. However, in that study the weight loss was relatively small, about $3 \%$ of body weight, and the rate of weight loss at the late weight loss phase (weeks 5-12) was 3 times less than at the beginning (weeks 1-4), so that the late phase resembled a weight maintenance condition. In the pan-European Diogenes study, Wang et al. [57] observed this phenomenon for 32 blood proteins and steroid hormones, indicating that it is probably not confined to a particular functional process in the body. Overall, the chance that these parameters maintain an adjusted level after weight loss seems to depend on the amount of lost weight and on the rate of weight loss. It has been proposed that at least $10 \%$ of body weight should be lost to achieve a long-term persistence in the change of these parameters [58].

Other factors like time after weight loss may be involved. Sjöström et al. [54] showed that the plasma levels of risk factors for cardiovascular defects after 2 years were back at their 


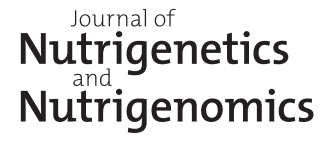

Fig. 1. Return effect of plasma components like ACE as observed during weight loss and follow-up. A hypothetical threshold is proposed beyond which the plasma level reflects weight regain. Whether the threshold is reached depends on the change of concentration during weight loss. Some plasma factors like ghrelin show a peaking course.

\begin{tabular}{l|l}
\hline J Nutrigenet Nutrigenomics 2012;5:13-25 \\
\hline $\begin{array}{l}\text { DOl: 10.1159/000337081 } \\
\text { Published online: March 30, } 2012\end{array}$ & $\begin{array}{l}\text { @ 2012 S. Karger AG, Basel } \\
\text { www.karger.com/jnn }\end{array}$ \\
\hline
\end{tabular}

Mariman et al.: Human Biology of Weight Maintenance after Weight Loss

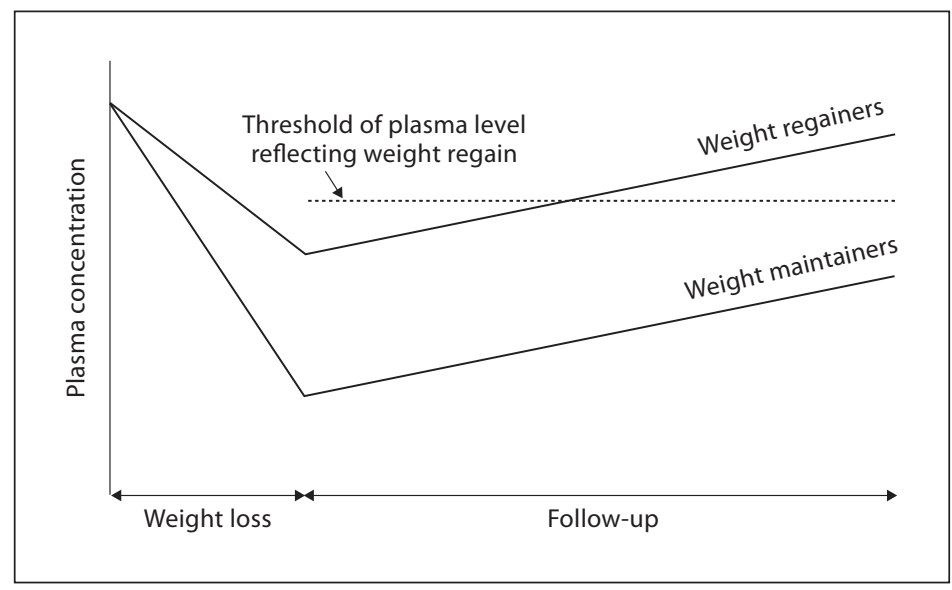

original values although a $5 \%$ body weight reduction was maintained. This suggests that with time the processes beyond the return effect lose their grip on weight regain. In the Diogenes study population, after the 6-month weight maintenance phase, both the females regaining weight and those maintaining weight after weight loss showed this return effect [57]. Yet, for various factors including angiotensin I-converting enzyme (ACE) and insulin, the final plasma concentration still significantly differed between weight regainers and maintainers, suggesting that for some factors the change in concentration during the weight loss phase has a strong influence. In figure 1 the course of the plasma concentration of a factor undergoing the return effect is shown. Assuming a threshold concentration for weight regain, both the change in plasma level during weight loss and the rate of reversal based on the homeostatic framework during the follow-up period would reflect on the risk for weight regain. A good example is ACE, of which a fold change of $<0.85$ during weight loss in women was found to be a strong predictor of subsequent weight maintenance $[57,59]$, which recently has been confirmed in men [60]. Leptin is also one of the factors that can show this return effect [57]. For at least one study, the course of leptin complies with that of figure 1 [48].

Assuming that the return effect of some of these factors is driving weight regain, timely resetting of gene expression might be a way to keep the plasma level at an adjusted lowrisk concentration. The homeostatic framework levels of plasma components can theoretically be linked to a fixed expression level of genes in pathways that are involved in the production and turnover of those components. Adjusting the plasma concentration would require resetting of gene expression by epigenetic mechanisms [61]. Methylation or demethylation of promoter sites is part of the mechanism of resetting the activity of genes. Interestingly, a study on the methylation status of the TNF $\alpha$ gene promoter in PBMCs showed that lower methylation was associated with successful weight loss by an 8 -week hypocaloric diet [62]. Unfortunately, no studies on weight maintenance after weight loss and promoter methylation have been reported so far, but it can be anticipated that such data will soon appear.

\section{Module 4: Cellular Resistance against Weight Loss}

The observations that factors like plasma leptin, baseline BMI, and fat mass are associated with the risk for weight regain point to an active role of the adipocytes. Recent experimental findings argue for a cellular mechanism underlying the poor success of weight main- 


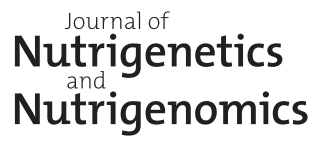

Fig. 2. Adipocyte cell stress. Model of an adipocyte-driven mechanism for weight regain after weight loss. Restoring of fat may be assisted by stress-induced changes in the secretion of adipocyte hormones upregulating energy intake in the individual.

\begin{tabular}{l|l}
\hline J Nutrigenet Nutrigenomics 2012;5:13-25 \\
\hline $\begin{array}{l}\text { DOI: 10.1159/000337081 } \\
\text { Published online: March 30, } 2012\end{array}$ & $\begin{array}{l}\text { @ 2012 S. Karger AG, Basel } \\
\text { www.karger.com/jnn }\end{array}$ \\
\hline
\end{tabular}

Mariman et al.: Human Biology of Weight Maintenance after Weight Loss

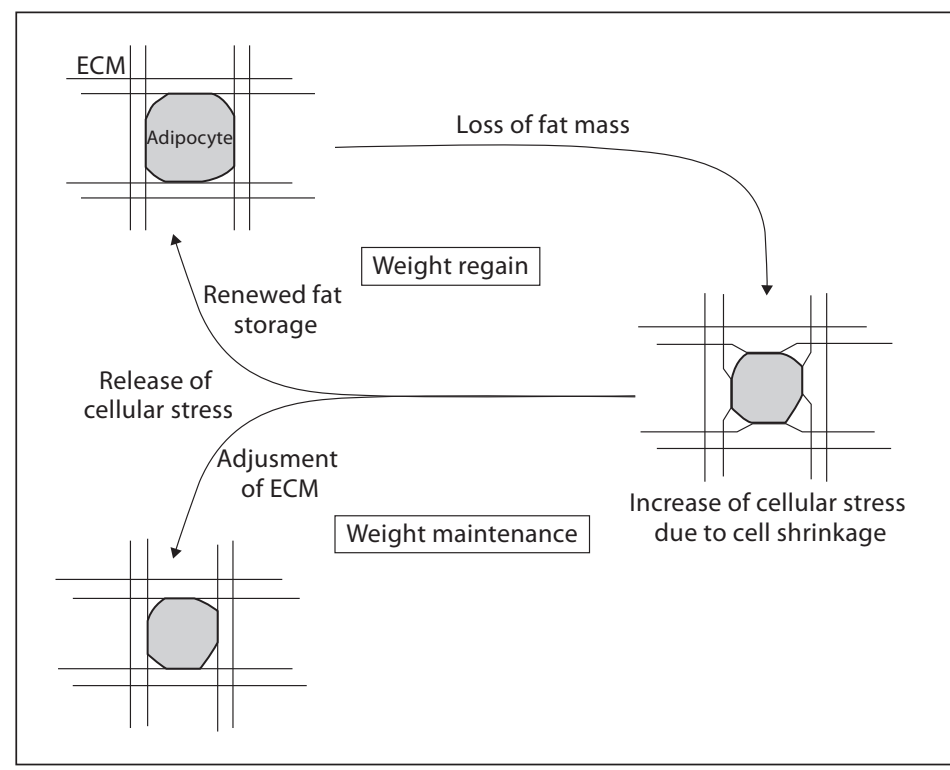

tenance after weight loss [39]. Using a proteome subtraction method [63] it was found that after losing weight and returning to energy balance, adipocytes prepare for re-storing triglycerides [39]. At the same time, differential expression of proteins belonging to the socalled stress proteome was observed $[39,64,65]$. Together, this indicates that, after losing fat, adipocytes experience cellular stress, which they try to alleviate by renewed fat storage (fig. 2). For this, they adjust their fatty acid metabolism and probably also the secretion profile of adipokines, changing whole body energy metabolism and energy intake of the host in such a way that the supply of sufficient fat to the adipose tissue is guaranteed. In this respect, the adipocyte-based demand for energy re-storage places people after weight loss at an increased risk for weight regain. Interestingly, this model complies with the extraordinary drop in the level of leptin as one of the adipokines.

The structural make-up of adipocytes may underlie the cellular stress during weight loss. Adipocytes are protected against mechanical disruption by a strong outer skeleton, a basal lamina. Mature adipocytes spend a lot of their energy on the maintenance of this strong extracellular matrix (ECM) [66], which is partly accounted for by the costly synthesis of collagen [67]. Overproduction of ECM components in obesity may lead to fibrosis [68, 69], which has been proposed to interfere with hypertrophy of omental adipocytes and with fat mass loss from subcutaneous adipocytes after surgery [70]. On the other hand, when people lose weight, the adipocytes lose fat and become smaller [71, 72]. As they shrink in volume, the ECM should be adjusted accordingly. However, under conditions of calorie restriction or increased energy expenditure, this process may be hampered, leading to traction forces between the cell and the surrounding ECM. It is assumed that this is the basis of adipocyte cellular stress and that this stress can most easily be relieved by letting the cell return to its original volume, i.e., by storing fat again [73].

The outcome of studies on the rate of weight loss suggests that a fast initial weight loss leads to a larger amount of lost weight, but that a gradual initial weight loss has a higher chance for long-term weight maintenance. This fits well with the model of cell stress, because one could imagine that gradual weight loss allows the adipose tissue to adjust to reduction of the fat content and leads to a lower level of cellular stress. However, controversial data exist, and a recent study by Nackers et al. [74] showed that fast initial weight loss was not ac- 
companied by a higher susceptibility for weight regain. The central idea, however, stands that during weight loss adipocytes develop resistance against loss of fat, which forms a driving force for fat re-storage and weight regain.

\section{Genetic Predisposition}

Although several hundreds of genes and loci are associated with obesity, only some of them have so far been implicated in the risk for weight regain. These genes are involved in different functional processes, and the question arises whether they comply with the four modules described above, or point to yet another process in weight maintenance.

The PPAR $\gamma$ gene is involved in the differentiation of pre-adipocytes to adipocytes, but in mature adipocytes PPAR $\gamma$ transactivates genes that promote fat oxidation [75]. Nicklas et al. [76] reported that the Pro12Ala polymorphism in the PPAR $\gamma$ gene was of influence on the change in fat oxidation during a 6-month intervention in which obese postmenopausal women lost $8 \%$ of their body weight. The group of women carrying at least one Ala allele showed a reduction of $19 \%$ in fat oxidation, whereas fat oxidation did not change in women with the Pro/Pro genotype. They observed that both carrying the Ala allele and the amount of fat oxidation reduction were predictors of weight regain. This finding was confirmed by Vogels et al. [50], who identified proportionally more Ala-allele carriers among subjects with unsuccessful (23.5\%) than with successful (9.5\%) weight maintenance. The Ala variant of the protein has lower binding affinity for the promoter element of target genes, which is accompanied by a lower transactivation [77], in that case fat oxidation.

The $\mathrm{G}$ allele of a $\mathrm{G} / \mathrm{C}$ polymorphism in the second intron of the glucocorticoid receptor gene has been shown to be associated with a higher BMI, abdominal visceral fat content, and waist-hip ratio $[78,79]$. In a study with 120 subjects who lost $8 \%$ of body weight on a 6 -week VLCD, it was found that subjects with the G/G genotype as compared to those with the G/C and $\mathrm{C} / \mathrm{C}$ genotypes had a significantly higher baseline BMI, a decreased disinhibition/emotional eating, and had significantly less feelings of hunger during weight loss. After a 1-year follow-up, the G/G genotype turned out to be a predictor of weight maintenance [50].

Another gene closely associated with adiposity is that for perilipin (PLIN), the major fat droplet coating protein of adipocytes. After losing $7 \mathrm{~kg}$ body weight in 6 weeks, 118 subjects were followed for 1 year, and parameters of adiposity were measured at 0,3 , and 12 months. Those data were compared with the genotypes and haplotypes of 5 polymorphisms in the PLIN gene. Various associations were observed between PLIN genotype and changes in adiposity parameters and leptin concentration over time with differences between men and women [80]. The results indicate that PLIN is involved in determining body weight as well as in weight maintenance.

The sympathetic nervous system has an important role in weight regulation. It is no surprise, therefore, that genes of this system are also candidates for being involved in weight maintenance. This was demonstrated by a study of Masuo et al. [81], in which it was shown that not only a high baseline fat mass but also a high norepinephrine level was a predictor of successful weight maintenance after weight loss. This high norepinephrine level was associated with the Gly16 allele of the $\beta 2$-adrenergic receptor gene.

Concerning physiologic factors, studies have been done on polymorphisms in both the adiponectin and leptin gene. For adiponectin, it was found that carriers of the A allele of the -11391 G/A polymorphism were more successful in weight maintenance than subjects with the GG genotype [82]. In the study of Erez et al. [49] with a 6-month weight loss phase, it was shown that two polymorphisms in the gene for leptin, rs4731426 and rs2071045, are associated with weight regain. 
Fig. 3. Network of functional processes. Network connecting the four functional modules, two of which (1 and 2) are related to the energy balance and another two (3 and 4) to resistance against weight loss. 1 = Energy expenditure by fat-free mass; 2 = energy regulation by metabolic hormones; 3 = physiologic resistance; 4 = cellular resistance. $\mathrm{BW}=$ Body weight.

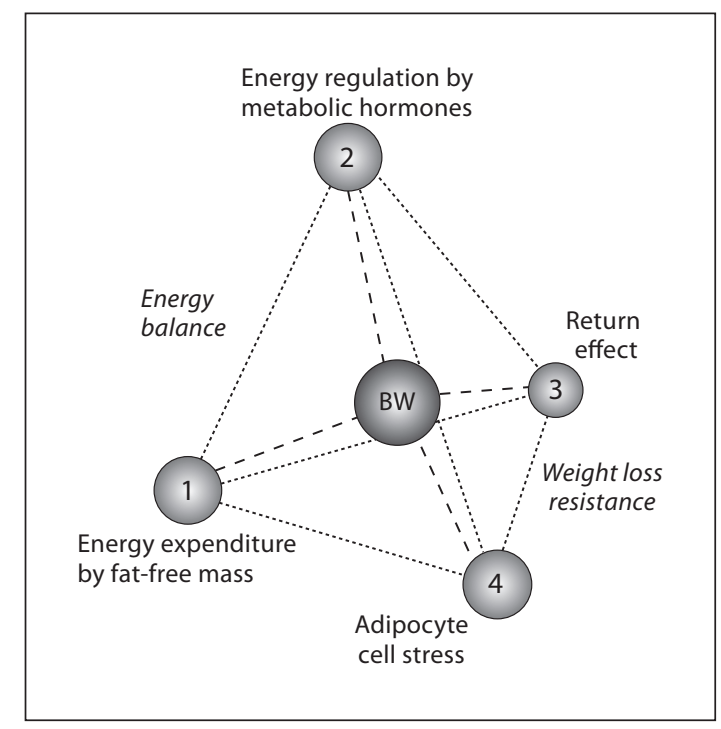

PPAR $\gamma$, the glucocorticoid receptor and PLIN polymorphisms influence body weight. Thus, it is possible that the predicting power for weight regain of the risk alleles of these polymorphisms acts through their association with a relatively high baseline BMI, which has repeatedly been associated with low risk for weight regain after weight loss [11, 12]. As such, these genes comply with module 1 in which metabolic activity and sparing of fat-free mass during weight loss is central. This also is true for the $\beta 2$-adrenergic receptor gene which influences the degree of lipolysis in adipose tissue as well as the activity of the fat-free mass via the sympathetic nervous system. Finally, adiponectin as an adipokine fits with module 4 as does leptin, which as metabolic hormones also link to module 2. Apparently, by the limited number of genes identified as genetic factors influencing weight maintenance no extra processes involved in weight maintenance regulation are put forward.

\section{Conclusion}

Weight maintenance after weight loss is complex, and just like other human traits it relies on external and intrinsic factors. Here, I have reviewed what is known about the latter category and assembled these factors into four functional modules (fig. 3). Two of them, one on energy expenditure and fat-free mass and one on energy regulation and metabolic hormones, promote weight regain by interfering with the energy balance, whereas the other two promote weight regain by physiological and cellular resistance against weight loss. At the same time, it is obvious that these modules are not merely opposite, but are connected to each other. This is most clearly shown by the results on leptin. When a person loses weight, adipocytes lose fat, accumulate stress, and dramatically lower their secretion of leptin. The leptin drop in the body is changing the feeling of hunger and satiety but also interferes with the functionality of the fat-free mass [42]. This is counteracted by the obese homeostatic framework that can only be changed after epigenetic resetting of gene expression. As such, reactions to weight loss constitute a dynamic interaction between various processes in the body. A similar picture emerges from the review of Maclean et al. [7], who included data from rodent studies. Adaptation of homeostasis is central in their model, and they focus on the feedback between brain and peripheral organs. An important 
role was also attributed to adipocytes, although cell size and not cellular stress was taken as a basis.

The functional units here referred to as 'modules' can be regarded as nodes in a network describing the complex interaction of intrinsic processes determining weight maintenance (fig. 3). Obviously, sex differences and genetic variation will to some extent personalize the network interactions, but in its present primitive state it can already be used to combine observations into predictions. As such, this network indicates that persons with a high baseline fat mass will most easily succeed in maintaining weight after weight loss, because they can lose fat without raising stress in the adipocytes and at the same time spare fat-free mass. Continued weight loss will lead to a more problematic phase of weight maintenance requiring extra measures like increased physical activity and a fat-free sparing composition of the diet. Eventually, the network may help to design novel therapeutic measures based on preventing the return effect of specific plasma factors or on preventing the accumulation of adipocyte cellular stress.

\section{Acknowledgements}

I want to thank Dr. P. Wang and Ing. F. Bouwman for critically reading the manuscript.

\section{Disclosure Statement}

The author is inventor of a patent application concerning the use of ACE as a predictor for weight regain.

\section{References}

1 Franz MJ, VanWormer JJ, Crain AL, Boucher JL, Histon T, Caplan W, Bowman JD, Pronk NP: Weight-loss outcomes: a systematic review and meta-analysis of weight-loss clinical trials with a minimum 1-year follow-up. J Am Diet Assoc 2007;107:1755-1767.

2 Wing RR, Phelan S: Long-term weight loss maintenance. Am J Clin Nutr 2005;82:222S-225S.

- Weiss EC, Galuska DA, Kettel Khan L, Gillespie C, Serdula MK: Weight regain in US adults who experienced substantial weight loss, 1999-2002. Am J Prev Med 2007;33:34-40.

4 Turk MW, Yang K, Hravnak M, Sereika SM, Ewing LJ, Burke LE: Randomized clinical trials of weight loss maintenance: a review. J Cardiovasc Nurs 2009;24:58-80.

5 Kraschnewski JL, Boan J, Esposito J, Sherwood NE, Lehman EB, Kephart DK, Sciamanna CN: Long-term weight loss maintenance in the United States. Int J Obes (Lond) 2010;34:1644-1654.

6 Bray GA: Obesity: maintenance of weight loss: setting our goals higher. Nat Rev Endocrinol 2010;6:657-658.

7 Maclean PS, Bergouignan A, Cornier MA, Jackman MR: Biology's response to dieting: the impetus for weight regain. Am J Physiol Regul Integr Comp Physiol 2011;301:R581-R600.

8 Arner P: Resistin: yet another adipokine tells us that men are not mice. Diabetologia 2005;48:2203-2205.

-9 Byrne SM, Cooper Z, Fairburn CG: Psychological predictors of weight regain in obesity. Behav Res Ther 2004;42: 1341-1356.

10 Vogels N, Westerterp-Plantenga MS: Categorical strategies based on subject characteristics of dietary restraint and physical activity, for weight maintenance. Int J Obes (Lond) 2005;29:849-857.

11 Vogels N, Westerterp-Plantenga MS: Successful long-term weight maintenance: a 2-year follow-up. Obesity (Silver Spring) 2007;15:1258-1266.

12 Vogels N, Diepvens K, Westerterp-Plantenga MS: Predictors of long-term weight maintenance. Obes Res 2005;13: 2162-2168.

13 Goyenechea E, Parra D, Crujeiras AB, Abete I, Martinez JA: A nutrigenomic inflammation-related PBMC-based approach to predict the weight-loss regain in obese subjects. Ann Nutr Metab 2009;54:43-51.

14 Weinsier RL, Schutz Y, Bracco D: Reexamination of the relationship of resting metabolic rate to fat-free mass and to the metabolically active components of fat-free mass in humans. Am J Clin Nutr 1992;55:790-794. 


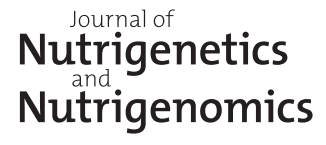

J Nutrigenet Nutrigenomics 2012;5:13-25

DOI: 10.1159/000337081

Published online: March 30, 2012

Mariman et al.: Human Biology of Weight Maintenance after Weight Loss

15 Johnstone AM, Murison SD, Duncan JS, Rance KA, Speakman JR: Factors influencing variation in basal metabolic rate include fat-free mass, fat mass, age, and circulating thyroxine but not sex, circulating leptin, or triiodothyronine. Am J Clin Nutr 2005;82:941-948.

$>16$

Blair D, Buskirk ER: Habitual daily energy expenditure and activity levels of lean and adult-onset and child-onset obese women. Am J Clin Nutr 1987;45:540-550.

-17 Ekelund U, Aman J, Yngve A, Renman C, Westerterp K, Sjostrom M: Physical activity but not energy expenditure is reduced in obese adolescents: a case-control study. Am J Clin Nutr 2002;76:935-941.

-18 Foster GD, Wadden TA, Kendrick ZV, Letizia KA, Lander DP, Conill AM: The energy cost of walking before and after significant weight loss. Med Sci Sports Exerc 1995;27:888-894.

$1995 ; 332: 621-628$

Doucet E, Imbeault P, St-Pierre S, Almeras N, Mauriege P, Despres JP, Bouchard C, Tremblay A: Greater than predicted decrease in energy expenditure during exercise after body weight loss in obese men. Clin Sci (Lond) 2003;105: 89-95.

$>23$

Doucet E, Tremblay A, Simoneau JA, Joanisse DR: Skeletal muscle enzymes as predictors of 24-h energy metabolism in reduced-obese persons. Am J Clin Nutr 2003;78:430-435.

24 Rosenbaum M, Hirsch J, Gallagher DA, Leibel RL: Long-term persistence of adaptive thermogenesis in subjects who have maintained a reduced body weight. Am J Clin Nutr 2008;88:906-912.

25 Mekary RA, Feskanich D, Hu FB, Willett WC, Field AE: Physical activity in relation to long-term weight maintenance after intentional weight loss in premenopausal women. Obesity (Silver Spring) 2010;18:167-174.

-26 Rosenbaum M, Kissileff HR, Mayer LE, Hirsch J, Leibel RL: Energy intake in weight-reduced humans. Brain Res 2010; 1350:95-102.

$>27$ Tremblay A, Chaput JP: Adaptive reduction in thermogenesis and resistance to lose fat in obese men. Br J Nutr 2009; 102:488-492.

28 Hong NS, Kim KS, Lee IK, Lind PM, Lind L, Jacobs DR, Lee DH: The association between obesity and mortality in the elderly differs by serum concentrations of persistent organic pollutants: a possible explanation for the obesity paradox. Int J Obes (Lond) 2011; DOI: 10.1038/ijo.2011.187.

-29 Major GC, Doucet E, Trayhurn P, Astrup A, Tremblay A: Clinical significance of adaptive thermogenesis. Int J Obes (Lond) 2007;31:204-212.

30 Rosenbaum M, Leibel RL: Adaptive thermogenesis in humans. Int J Obes (Lond) 2010;34(suppl 1):S47-S55.

-31 Pereira MA, Swain J, Goldfine AB, Rifai N, Ludwig DS: Effects of a low-glycemic load diet on resting energy expenditure and heart disease risk factors during weight loss. Jama 2004;292:2482-2490.

-32 Abete I, Astrup A, Martinez JA, Thorsdottir I, Zulet MA: Obesity and the metabolic syndrome: role of different dietary macronutrient distribution patterns and specific nutritional components on weight loss and maintenance. Nutr Rev 2010;68:214-231.

33 Paddon-Jones D, Westman E, Mattes RD, Wolfe RR, Astrup A, Westerterp-Plantenga M: Protein, weight management, and satiety. Am J Clin Nutr 2008;87:1558S-1561S.

-34 Westerterp-Plantenga MS, Nieuwenhuizen A, Tome D, Soenen S, Westerterp KR: Dietary protein, weight loss, and weight maintenance. Annu Rev Nutr 2009;29:21-41.

-35 Layman DK: Protein quantity and quality at levels above the RDA improves adult weight loss. J Am Coll Nutr 2004; 23:631S-636S.

-36 Morrison CD, Xi X, White CL, Ye J, Martin RJ: Amino acids inhibit Agrp gene expression via an mTOR-dependent mechanism. Am J Physiol Endocrinol Metab 2007;293:E165-E171.

-37 Larsen TM, Dalskov S, van Baak M, Jebb S, Kafatos A, Pfeiffer A, Martinez JA, Handjieva-Darlenska T, Kunesova M, Holst C, Saris WH and Astrup A: The Diet, Obesity and Genes (Diogenes) Dietary Study in eight European countries - a comprehensive design for long-term intervention. Obes Rev 2010;11:76-91.

-38 Larsen TM, Dalskov SM, van Baak M, Jebb SA, Papadaki A, Pfeiffer AF, Martinez JA, Handjieva-Darlenska T, Kunesova M, Pihlsgard M, Stender S, Holst C, Saris WH, Astrup A: Diets with high or low protein content and glycemic index for weight-loss maintenance. N Engl J Med 2010;363:2102-2113.

-39 Bouwman FG, Claessens M, van Baak MA, Noben JP, Wang P, Saris WH, Mariman EC: The physiologic effects of caloric restriction are reflected in the in vivo adipocyte-enriched proteome of overweight/obese subjects. J Proteome Res 2009;8:5532-5540.

40 Sumithran P, Prendergast LA, Delbridge E, Purcell K, Shulkes A, Kriketos A, Proietto J: Long-term persistence of hormonal adaptations to weight loss. N Engl J Med 2011;365:1597-1604.

41 Ozcelik O, Dogan H, Celik H, Ayar A, Serhatlioglu S and Kelestimur H: Effects of different weight loss protocols on serum leptin levels in obese females. Physiol Res 2005;54:271-277.

-42 Rosenbaum M, Goldsmith R, Bloomfield D, Magnano A, Weimer L, Heymsfield S, Gallagher D, Mayer L, Murphy E, Leibel RL: Low-dose leptin reverses skeletal muscle, autonomic, and neuroendocrine adaptations to maintenance of reduced weight. J Clin Invest 2005;115:3579-3586.

-43 Ahima RS, Prabakaran D, Mantzoros C, Qu D, Lowell B, Maratos-Flier E, Flier JS: Role of leptin in the neuroendocrine response to fasting. Nature 1996;382:250-252. 


\section{Nutrigenetics Nutrigenomics}

\begin{tabular}{l|l}
\hline J Nutrigenet Nutrigenomics 2012;5:13-25 \\
\hline $\begin{array}{l}\text { DOI: 10.1159/000337081 } \\
\text { Published online: March 30, } 2012\end{array}$ & $\begin{array}{l}\text { @ 2012 S. Karger AG, Basel } \\
\text { www.karger.com/jnn }\end{array}$ \\
\hline
\end{tabular}

Mariman et al.: Human Biology of Weight Maintenance after Weight Loss

-44 Rosenbaum M, Sy M, Pavlovich K, Leibel RL, Hirsch J: Leptin reverses weight loss-induced changes in regional neural activity responses to visual food stimuli. J Clin Invest 2008;118:2583-2591.

-45 Goldsmith R, Joanisse DR, Gallagher D, Pavlovich K, Shamoon E, Leibel RL, Rosenbaum M: Effects of experimental weight perturbation on skeletal muscle work efficiency, fuel utilization, and biochemistry in human subjects. Am J Physiol Regul Integr Comp Physiol 2010;298:R79-R88.

-46 Rosenbaum M, Murphy EM, Heymsfield SB, Matthews DE, Leibel RL: Low dose leptin administration reverses effects of sustained weight-reduction on energy expenditure and circulating concentrations of thyroid hormones. J Clin Endocrinol Metab 2002;87:2391-2394.

Welt CK, Chan JL, Bullen J, Murphy R, Smith P, DePaoli AM, Karalis A, Mantzoros CS: Recombinant human leptin in women with hypothalamic amenorrhea. N Engl J Med 2004;351:987-997.

-48 Crujeiras AB, Goyenechea E, Abete I, Lage M, Carreira MC, Martinez JA, Casanueva FF: Weight regain after a dietinduced loss is predicted by higher baseline leptin and lower ghrelin plasma levels. J Clin Endocrinol Metab 2010;95: 5037-5044.

-49 Erez G, Tirosh A, Rudich A, Meiner V, Schwarzfuchs D, Sharon N, Shpitzen S, Bluher M, Stumvoll M, Thiery J, Fiedler GM, Friedlander Y, Leiterstdorf E, Shai I: Phenotypic and genetic variation in leptin as determinants of weight regain. Int J Obes (Lond) 2011;35:785-792.

-50 Vogels N, Mariman EC, Bouwman FG, Kester AD, Diepvens K, Westerterp-Plantenga MS: Relation of weight maintenance and dietary restraint to peroxisome proliferator-activated receptor gamma2, glucocorticoid receptor, and ciliary neurotrophic factor polymorphisms. Am J Clin Nutr 2005;82:740-746.

51 Wing RR, Sinha MK, Considine RV, Lang W, Caro JF: Relationship between weight loss maintenance and changes in serum leptin levels. Horm Metab Res 1996;28:698-703.

52 Garcia JM, Iyer D, Poston WS, Marcelli M, Reeves R, Foreyt J, Balasubramanyam A: Rise of plasma ghrelin with weight loss is not sustained during weight maintenance. Obesity (Silver Spring) 2006;14:1716-1723.

53 Gilbert JA, Joanisse DR, Chaput JP, Miegueu P, Cianflone K, Almeras N, Tremblay A: Milk supplementation facilitates appetite control in obese women during weight loss: a randomised, single-blind, placebo-controlled trial. Br J Nutr 2011;105:133-143.

-54 Sjöström L, Rissanen A, Andersen T, Boldrin M, Golay A, Koppeschaar HP, Krempf M: Randomised placebo-controlled trial of orlistat for weight loss and prevention of weight regain in obese patients. European Multicentre Orlistat Study Group. Lancet 1998;352:167-172.

55 Kovacs EM, Lejeune MP, Nijs I, Westerterp-Plantenga MS: Effects of green tea on weight maintenance after bodyweight loss. Br J Nutr 2004;91:431-437.

56 Diepvens K, Kovacs EM, Vogels N, Westerterp-Plantenga MS: Metabolic effects of green tea and of phases of weight loss. Physiol Behav 2006;87:185-191.

57 Wang P, Holst C, Astrup A, Bouwman FG, van Otterdijk S, Wodzig WK, Andersen MR, van Baak MA, Rasmussen LG, Alfredo Martinez J, Jebb SA, Pfeiffer AF, Kafatos A, Handjieva-Darlenska T, Hlavaty P, Saris WH, Mariman EC: Blood profiling of proteins and steroids during weight maintenance with manipulation of dietary protein level and glycaemic index. Br J Nutr 2012;107:106-119.

58 Sjöström CD, Lissner L, Sjöström L: Relationships between changes in body composition and changes in cardiovascular risk factors: the SOS Intervention Study. Swedish Obese Subjects. Obes Res 1997;5:519-530.

59 Wang P, Holst C, Andersen MR, Astrup A, Bouwman FG, van Otterdijk S, Wodzig WKWH, van Baal MA, Larsen TM, Jebb SA, Kafatos A, Preiffer AFH, Martinez JA, Hanjieva-Darlenska T, Kunesova M, Saris WHM, Mariman EC: Blood profile of proteins and steroid hormones predicts weight change after weight loss with interactions of dietary protein level and glycemic index. PLoS ONE 2011;6:e16773.

60 Wang P, Holst C, Wodzig WK, Andersen MR, Astrup A, van Baak MA, Larsen TM, Jebb SA, Kafatos A, Pfeiffer AF, Martinez JA, Handjieva-Darlenska T, Kunesova M, Viguerie N, Langin D, Saris WH, Mariman EC: Circulating ACE is a predictor of weight loss maintenance not only in overweight and obese women, but also in men. Int J Obes (Lond) 2012; DOI: $10.1038 /$ ijo.2011.278. Mariman EC: Epigenetic manifestations in diet-related disorders. J Nutrigenet Nutrigenomics 2008;1:232-239.

62 Campion J, Milagro FI, Goyenechea E, Martinez JA: TNF-alpha promoter methylation as a predictive biomarker for weight-loss response. Obesity (Silver Spring) 2009;17:1293-1297.

-63 Claessens M, Saris WH, Bouwman FG, Evelo CT, Hul GB, Blaak EE, Mariman EC: Differential valine metabolism in adipose tissue of low and high fat-oxidizing obese subjects. Proteomics Clin Appl 2007;1:1306-1315.

64 Wang P, Bouwman FG, Mariman EC: Generally detected proteins in comparative proteomics - a matter of cellular stress response? Proteomics 2009;9:2955-2966.

65 Mariman EC: 2DE-proteomics meta-data indicate the existence of distinct cellular stress-responsive mechanisms. Expert Rev Proteomics 2009;6:337-339.

66 Bouwman F, Renes J, Mariman E: A combination of protein profiling and isotopomer analysis using matrix-assisted laser desorption/ionization-time of flight mass spectrometry reveals an active metabolism of the extracellular matrix of 3T3-L1 adipocytes. Proteomics 2004;4:3855-3863.

67 Mariman EC, Wang P: Adipocyte extracellular matrix composition, dynamics and role in obesity. Cell Mol Life Sci 2010;67:1277-1292.

68 Divoux A, Clement K: Architecture and the extracellular matrix: the still unappreciated components of the adipose tissue. Obes Rev 2011;12:e494-e503. 


\section{Nutrigenetics utrigenomics}

\begin{tabular}{l|l}
\hline J Nutrigenet Nutrigenomics 2012;5:13-25 \\
\hline $\begin{array}{l}\text { DOI: 10.1159/000337081 } \\
\text { Published online: March 30, } 2012\end{array}$ & $\begin{array}{l}\text { @ 2012 S. Karger AG, Basel } \\
\text { www.karger.com/jnn }\end{array}$ \\
\hline
\end{tabular}

Mariman et al.: Human Biology of Weight Maintenance after Weight Loss

69 Khan T, Muise ES, Iyengar P, Wang ZV, Chandalia M, Abate N, Zhang BB, Bonaldo P, Chua S, Scherer PE: Metabolic dysregulation and adipose tissue fibrosis: role of collagen VI. Mol Cell Biol 2009;29:1575-1591.

70 Divoux A, Tordjman J, Lacasa D, Veyrie N, Hugol D, Aissat A, Basdevant A, Guerre-Millo M, Poitou C, Zucker JD, Bedossa P, Clement K: Fibrosis in human adipose tissue: composition, distribution, and link with lipid metabolism and fat mass loss. Diabetes 2010;59:2817-2825.

-71 Pasarica M, Tchoukalova YD, Heilbronn LK, Fang X, Albu JB, Kelley DE, Smith SR, Ravussin E: Differential effect of weight loss on adipocyte size subfractions in patients with type 2 diabetes. Obesity (Silver Spring) 2009;17:1976-1978.

-72 You T, Murphy KM, Lyles MF, Demons JL, Lenchik L, Nicklas BJ: Addition of aerobic exercise to dietary weight loss preferentially reduces abdominal adipocyte size. Int J Obes (Lond) 2006;30:1211-1216.

73 Eastman Q: Very low calorie diet makes adipocytes 'scream'. J Proteome Res 2009;8:5408.

74 Nackers LM, Ross KM, Perri MG: The association between rate of initial weight loss and long-term success in obesity treatment: does slow and steady win the race? Int J Behav Med 2010;17:161-167.

75 Wang P, Renes J, Bouwman F, Bunschoten A, Mariman E, Keijer J: Absence of an adipogenic effect of rosiglitazone on mature 3T3-L1 adipocytes: increase of lipid catabolism and reduction of adipokine expression. Diabetologia 2007;50: 654-665.

76 Nicklas BJ, van Rossum EF, Berman DM, Ryan AS, Dennis KE, Shuldiner AR: Genetic variation in the peroxisome proliferator-activated receptor-gamma2 gene (Pro12Ala) affects metabolic responses to weight loss and subsequent weight regain. Diabetes 2001;50:2172-2176.

77 Deeb SS, Fajas L, Nemoto M, Pihlajamaki J, Mykkanen L, Kuusisto J, Laakso M, Fujimoto W, Auwerx J: A Pro12Ala substitution in PPARgamma2 associated with decreased receptor activity, lower body mass index and improved insulin sensitivity. Nat Genet 1998;20:284-287.

78 Rosmond R, Chagnon YC, Holm G, Chagnon M, Perusse L, Lindell K, Carlsson B, Bouchard C, Bjorntorp P: A glucocorticoid receptor gene marker is associated with abdominal obesity, leptin, and dysregulation of the hypothalamicpituitary-adrenal axis. Obes Res 2000;8:211-218.

79 Buemann B, Vohl MC, Chagnon M, Chagnon YC, Gagnon J, Perusse L, Dionne F, Despres JP, Tremblay A, Nadeau A, Bouchard C: Abdominal visceral fat is associated with a BclI restriction fragment length polymorphism at the glucocorticoid receptor gene locus. Obes Res 1997;5:186-192.

-80 Soenen S, Mariman EC, Vogels N, Bouwman FG, den Hoed M, Brown L, Westerterp-Plantenga MS: Relationship between perilipin gene polymorphisms and body weight and body composition during weight loss and weight maintenance. Physiol Behav 2009;96:723-728.

81 Masuo K, Katsuya T, Kawaguchi H, Fu Y, Rakugi H, Ogihara T, Tuck ML: Rebound weight gain as associated with high plasma norepinephrine levels that are mediated through polymorphisms in the beta2-adrenoceptor. Am J Hypertens 2005;18:1508-1516.

82 Goyenechea E, Collins LJ, Parra D, Abete I, Crujeiras AB, O’Dell SD, Martinez JA: The -11391 G/A polymorphism of the adiponectin gene promoter is associated with metabolic syndrome traits and the outcome of an energy-restricted diet in obese subjects. Horm Metab Res 2009;41:55-61. 